DOI 10.31558/2307-2318.2020.3.23
УДК 314.8:332.1:338.2
JЕL: I31, J24, D7

Томчук O.B.,

к.е.н., доцент, доцент кафедри менеджменту та поведінкової економіки Донецького національного університету імені Василя Стуса

ORCID: 0000-0002-1817-7483

o.tomchuk@donnu.edu.ua

\title{
СОЦІАЛЬНО-ЕКОНОМІЧНІ ДЕТЕРМІНАНТИ РОЗВИТКУ ЛЮДСЬКОГО ПОТЕНЦІАЛУ ТЕРИТОРІЙ: ТЕОРЕТИЧНИЙ ТА ПРИКЛАДНИЙ АСПЕКТ
}

Статтю присвячено аналізу теоретико-методологічних підходів до визначення соиіально-економічних детермінант розвитку людського потенціалу територій 3 позицій сучасної людиноцентрованої концепції економічного і регіонального зростання. Проаналізовано взаємозв'язок сучасних теорій економічного зростання та теорій просторового розвитку з розвитком людського потенціалу територій (регіонів), на основі яких обтрунтовано соціально-економічні детермінанти розвитку людського потениіалу, які визначають потребу, умови і параметри його формування. Відокремлено низку показників їх оцінювання і вимірювання, щуо згруповано у чотири блоки показників (економічний та просторовий розвиток, рівень добробуту, розвиток знаннєвої та креативної економіки), здійснено їх теоретико-методологічне обгрунтування. 3 метою апробаиії пропонованого підходу проведено компаративний аналіз і оиінку соціальноекономічних детермінант розвитку людського потенціалу обраних за типовими ознаками регіонів. На основі результатів розрахунку загального індексу сочіальноекономічних детермінант розвитку людського потенціалу регіону виявлено проблемні сфери, регулювання яких потребує підвищеної уваги регіональних органів влади в контексті розробки і удосконалення стратегічних програм регіонального розвитку.

Ключові слова: сочіально-економічні детермінанти розвитку людського потенціалу, людський потенціал територій, концепція людського розвитку, теорії економічного зростання.

Рис. - 2, Табл. - 3, Літ. - 22

Томчук О.В.

к.э.н., доцент кафедры менеджмента и поведенческой экономики Донецкого национального университета имени Васыля Стуса

ORCID: 0000-0002-1817-7483

o.tomchuk@donnu.edu.ua

\section{СОЦИАЛЬНО-ЭКОНОМИЧЕСКИЕ ДЕТЕРМИНАНТЫ РАЗВИТИЯ ЧЕЛОВЕЧЕСКОГО ПОТЕНЦИАЛА ТЕРРИТОРИЙ: ТЕОРЕТИЧЕСКИЙ И ПРИКЛАДНОЙ АСПЕКТ}

Статья посвящена анализу теоретико-методологических подходов к определению сочииально-экономических 
территорий с позиций современной человекочентрированной концепџии экономического u регионального роста. Проанализирована взаимосвязь современных теорий экономического роста и теорий пространственного развития с развитием человеческого потенциала территорий (регионов), на основе которых обоснованы сочиально-экономические детерминанты развития человеческого потенциала, которые определяют необходимость, условия и параметры его формирования. Обособлен ряд показателей их оченки и измерения, сгруппированных в четыре блока (экономическое и пространственное развитие, уровень благополучия, развитие знаниевой и креативной экономики), осуществлено их теоретико-методологическое обоснование. С иелью апробации предлагаемого подхода проведено компаративный анализ и оценку социально-экономических детерминант развития человеческого потенциала избранных по типичными признаками регионов. На основе результатов расчета общего индекса сочиально-экономических детерминант развития человеческого потенциала региона выявлены проблемные сферы, регулирование которых требует повышенного внимания региональных органов власти в контексте разработки и усовершенствования стратегических программ регионального развития.

Ключевые слова: социально-экономические детерминанты развития человеческого потенциала, человеческий потенциал территорий, концепџия человеческого развития, теории экономического роста.

Рис. -2 , Табл. -3 , Лит. -22

\section{O. Tomchuk,}

$\mathrm{PhD}$ in economics, Associate Prof., Associate Professor of the Department of Management and Behavioral Economics, Vasyl' Stus Donetsk National University

ORCID: 0000-0002-1817-7483

o.tomchuk@donnu.edu.ua

\section{SOCIIAL AND ECONOMIC DETERMINANTS OF HUMAN POTENTIAL DEVELOPMENT OF TERRITORIES: THEORETICAL AND APPLIED ASPECT}

The article is devoted to the analysis of theoretical and methodological approaches to determining the social and economic determinants of the human potential of territories development from the standpoint of the modern human-centered concept economic and regional growth. The interrelation of economic growth modern theories and spatial development theories with the human potential of territories (regions) development is analyzed, on the basis of which social and economic determinants of human potential development are substantiated, which determine the need, conditions and parameters for its formation. Several indicators for evaluation and measurement of social and economic determinants of human potential development have been separated, grouped into four blocks of indicators (economic and spatial development, level of well-being, development of knowledge and creative economy), its theoretical and methodological substantiation has been carried out. In order to test the proposed approach, a comparative analysis and assessment of social and economic determinants of human potential development of the regions selected by typical characteristics. Based on the results of calculating the general index of social and economic determinants of regional human development, problem areas have been identified, the regulation of which 
requires increased attention of regional authorities in the context of developing and improving strategic programs for regional development.

Keywords: social and economic determinants of human potential development, human potential of territories, the concept of human development, theories of economic growth.

Fig. -2 , Tabl. -3 , Ref. -22

Постановка проблеми. Потреба в розвитку людського потенціалу країни та іiі окремих територій обгрунтована в сучасних концепціях економічного розвитку i зростання. Ще в рамках класичної і неокласичної теорії було доведено: фізична здатність економіки до зростання обумовлюється кількістю та якістю природних ресурсів, кількістю та якістю трудових ресурсів, обсягами капіталу країни, рівнем технології. При цьому людський чинник виробництва, а саме - населення та його економічна активність вважався найважливішим для забезпечення економічного розвитку. Сьогодні виникла низка нових концепцій економічного розвитку і зростання, де людському чиннику відводиться провідна роль, що виходять із положення про право людини на гідне існування і вільний розвиток, спрямовані на розширення можливостей нарощення свого внутрішнього потенціалу, підвищення креативності, яке забезпечується створенням базових та розширених умов для довготривалого і здорового життя, вільного доступу до знань, гідної професійної і особистісної реалізації, в кінцевому результаті дозволяючи досягти довготривалої позитивної соціально-економічної динаміки. Під впливом цих концепцій трансформуються теоретико-методологічні основи забезпечення сталого просторового розвитку, що вимагає перегляду ролі людського потенціалу територій, 3 огляду на його зростаючу значущість, розробки відповідних механізмів його формування, нарощення та використання для досягнення стратегічних цілей. За такого підходу особливої актуальності набуває аналіз сукупності чинників, які визначають та одночасно обмежують ефективне формування та розвиток людського потенціалу (його детермінант), доповнення усталеної схеми аналізу чинників кількісного та якісного типу (демографічні, фізіологічні, розвиток освітньої інфраструктури, можливості зайнятості, рівень соціального забезпечення, можливості культурного розвитку) системою чинників, які формують потребу в розвитку людського потенціалу та які визначають специфічні регіональні умови його розвитку.

Аналіз останніх досліджень і публікацій. Проблематика ефективного формування, нарощення та використання людського потенціалу тривалий період часу перебуває у полі зору багатьох вчених та дослідників (О. Грішнової, М. Голанського, Н. Єгорової, Л. Зайцевої, В. Логвіненка, Б. Хомелянського та ін.). В роботах зазначених вчених досліджуються базові складові, що напряму впливають на рівень людського потенціалу, визначають макро- та мікросередовище його формування. В той же час, зростання значущості людського розвитку в сучасній соціально-економічній парадигмі обумовлює появу нових теорій та концепцій економічного розвитку та зростання: теорія ендогенного зростання П. Ромера [1] та Р. Лукаса [2], концепція структурної трансформації Р. Хаусмана [3], концепція економіки, що базується на знаннях [4], теорія економіки навчання Б.-Е. Люндвалла [5], теорія креативної економіки, концепція цифрової економіки та Індустрії 4.0 та ін. Це в свою чергу спричиняє зміни у підходах до концепції просторового розвитку та зростання значущості теорій саморозвитку регіону [6-8], теорії центр-периферійного територіального розвитку [9] та «полюсів зростання» [10], теорії міських агломерацій [11], концепції сталого розвитку [12]. 3 огляду на це необхідним представляється аналіз новітніх наукових підходів в контексті нарощення людського потенціалу територій, визначення ключових соціально- 
економічних детермінант, що обумовлюють його ефективний розвиток, розробка i апробація науково-методичного інструментарію для вимірювання ступеня їх впливу 3 метою побудови дієвих стратегій і програм територіального розвитку, наведене визначає мету написання статті.

Виклад основного матеріалу. Людський потенціал $є$ складним соціальноекономічним явищем, формування і розвиток якого залежить від безлічі умов і чинників, що в комплексі визначаються як детермінанти (від лат. «determinantis» - чинник, який визначає, обмежує). Відповідно до наукових висновків і підходів багатьох вітчизняних вчених до дослідження факторів та умов розвитку людського потенціалу території, їх можна умовно розділити на демографічні, соціальні, інституційні, екологічні, економічні та науково-технічні. Таке розмежування свідчить про багатофакторність цього явища, складні умови його відтворення, обумовлює наявність численних проблем людського розвитку не лише в Україні, але й в розвинених країнах.

3 розвитком науки і технологій виникла низка нових концепцій економічного розвитку і зростання, де людському чиннику відводиться провідна роль. Так, теорія ендогенного зростання орієнтується на внутрішні джерела розвитку, передусім розвиток людини. Її засновники [1-2] вважають зростання результатом науково-технічного прогресу внаслідок інвестицій у розвиток людського капіталу, знань, науки. Тобто виробництво людського капіталу, як головного чинника економічного розвитку. здійснюється в секторі освіти і являє собою сукупність компетенцій працівників, зростання частки населення з вищою освітою тощо.

В концепиії структурної трансформації економіки економічне зростання обумовлюється прогресивною зміною структури економіки, розвитком або формуванням високотехнологічних секторів, які стають драйверами економічного зростання. Неодмінною умовою розвитку високотехнологічних сфер є високопрофесійне кадрове забезпечення, в основі якого лежить якісний розвиток людського потенціалу.

В середині 90-х років XX ст. з'являються теорії так званої «нової економіки», які безпосередньо стосуються розвитку людського потенціалу як країни, так і регіонів. Однією з них є конщепція економіки, що базується на знаннях («knowledge-based есопоту»), яка розроблена фахівцями Організації економічного співробітництва i розвитку (ОЕСР) [4]. Динамічний розвиток науково-технічного прогресу призводить до того, що знання і технології стають провідними чинниками продуктивності та економічного зростання, з одночасним скороченням частки фізичної праці та зростанням частки праці, пов'язаної з виробництвом і обробкою знань та інформації. Тому, забезпечення виробництва, розподілу і використання знань та інформації є важливою умовою розвитку країни та окремих територій, а інвестиції у дослідження і розробки, освіту населення, підготовку кадрів - чинниками розвитку [13, с.57].

Близькою за сутністю є теорія економіки навчання («learning economy») [5]. Вона виходить $з$ того, в сучасних умовах зростаючих темпів технологічних змін та інновацій важливу роль відіграють не лише здобуті знання, які швидко «старіють», а сам процес навчання. Здатність навчатися стає критичною для економічного успіху індивідуумів, фірм, регіонів і національних економік. Отже, рівень знань людини, що характеризує якість людського потенціалу, є ключовим для розвитку сучасної економіки.

На початку 2000-х років виникає теорія креативної економіки, яка також має безпосереднє відношення до людського потенціалу. Основні засади цієї теорії викладено в працях Дж. Хоукінса, Р. Флориди та Ч. Лендрі [14], які обгрунтовують креативність як найважливіший чинник успішного розвитку нової економіки. Для креативного класу суспільства характерні талант, індивідуальні творчі здібності, творча уява і навички, 
висока мотивація до творчої діяльності, які створюють унікальні продукти і послуги. Особливо це проявляється у містах, оскільки людський інтелект, творчі здібності і креативний потенціал мешканців $\epsilon$ основою розвитку сучасних міст в умовах постіндустріальної трансформації.

Ще один підхід пов'язаний з концепцію цุифрової економіки та індустрї 4.0, які виникають на початку XXI століття внаслідок розвитку комп'ютерних засобів, Інтернету, інформаційно-комунікаційних та цифрових технологій. Рушійною силою цифрової економіки є людський капітал, тобто знання, таланти, навички, вміння, досвід, інтелект людей [15], в основі чого лежить всебічний розвиток людини. Індустрія 4.0 наступний етап цифрової трансформації виробничих підприємств, який супроводжується прискореним впровадженням нових технологій, таких як промисловий інтернет речей, аналітика великих даних, штучний інтелект, нове покоління роботів, доповнена реальність тощо, системне викладення яких здійснено К. Швабом [16], що призводить до зміни бізнес-моделей і значного прискорення інноваційного розвитку. Такі потужні технологічні трансформації в економіці вимагають якісно нового людського і трудового потенціалу, який володіє значним інтелектом, сучасними знаннями, цифровими навичками, здатністю до безперервного навчання, аналізу все зростаючого обсягу інформації.

Узагальнення ролі цих теорій в розвитку людського потенціалу територій наведено в табл. 1.

Таблиця 1

Взаємозв'язок сучасних теорій економічного зростання з розвитком людського потенціалу регіонів

\begin{tabular}{|c|c|c|}
\hline Teopiï & Автори & Значення для людського потенціалу \\
\hline $\begin{array}{l}\text { Теорія ендогенного зростання: } \\
\text { використання внутрішніх джерел } \\
\text { розвитку, передусім потенціалу людини }\end{array}$ & $\begin{array}{l}\text { П. Ромер } \\
\text { Р. Е. Лукас }\end{array}$ & $\begin{array}{l}\text { Обгрунтовує необхідність розвитку знань, } \\
\text { підвищення частки населення } 3 \text { вищою освітою, } \\
\text { поширення навчання на практиці }\end{array}$ \\
\hline $\begin{array}{l}\text { Концепція структурної трансформації } \\
\text { економіки: під впливом НТП іде } \\
\text { прогресивна зміна структури економіки, } \\
\text { розвиток або формуванням } \\
\text { високотехнологічних секторів }\end{array}$ & $\begin{array}{l}\text { Р. Хаусман } \\
\text { Д. Родрік }\end{array}$ & $\begin{array}{l}\text { Для розвитку високотехнологічних сфер } \\
\text { необхідно кадрове забезпечення, в основі якого } \\
\text { лежить якісний розвиток людського потенціалу на } \\
\text { основі зростання рівня освіти і сучасних } \\
\text { компетенцій }\end{array}$ \\
\hline $\begin{array}{l}\text { Теорії економіки, що базується на } \\
\text { знаннях, та економіки навчання: знання і } \\
\text { технології є провідними чинниками } \\
\text { економічного розвитку, а ключовим } \\
\text { фактором - здатність людини до навчання }\end{array}$ & $\begin{array}{l}\text { ОЕСР } \\
\text { Б.-Е. Люндвалл }\end{array}$ & $\begin{array}{l}\text { Обгрунтовує ключову значимість якісних освітніх } \\
\text { характеристик людського потенціалу в сучасному } \\
\text { розвитку та необхідність забезпечення якісного і } \\
\text { безперервного навчання населення, } \\
\text { нагромадження знань }\end{array}$ \\
\hline $\begin{array}{l}\text { Теорія креативної економіки і } \\
\text { креативного класу: все більшу роль в } \\
\text { суспільному розвитку відіграють } \\
\text { представники творчих професій та } \\
\text { креативні індустрії }\end{array}$ & $\begin{array}{l}\text { Р. Флорида } \\
\text { Ч. Лэндри }\end{array}$ & $\begin{array}{l}\text { Обгрунтовує зростаючу роль творчих рис людини } \\
\text { (таланту, індивідуальних здібностей, творчої уяви, } \\
\text { високої мотивації до творчої діяльності) та } \\
\text { необхідність забезпечення розвитку творчих } \\
\text { здібностей людини }\end{array}$ \\
\hline $\begin{array}{l}\text { Концепції цифрової економіки та індустрії } \\
\text { 4.0: впровадження цифрових технологій в } \\
\text { усі сфери життя, розвиток індустрії на } \\
\text { основі промислового ІоТ, аналітики } \\
\text { великих даних та ін. }\end{array}$ & $\begin{array}{l}\text { Х. Кагерман, } \\
\text { В.-Д. Лукас, } \\
\text { В. Вальстер } \\
\text { К. Шваб }\end{array}$ & $\begin{array}{l}\text { Формується потреба в якісно новому людському } \\
\text { потенціалі, який володіє значним інтелектом, } \\
\text { сучасними знаннями, цифровими навичками, } \\
\text { здатністю до безперервного навчання, високою } \\
\text { мобільністю }\end{array}$ \\
\hline
\end{tabular}
Джерело: розроблено автором на основі [1-5; 14-16]

Окрім того, стан і динаміка людського потенціалу територій також значною мірою залежить від специфіки розвитку адміністративно-територіального району, регіональних та територіальних параметрів розвитку: просторового розміщення населення й економічних об'єктів, структури економіки, технологічних, інноваційних, інфраструктурних здобутків, які визначають соціально-економічний стан розвитку території і якість життя населення. 
Зростання значущості соціально-економічних систем локального рівня у забезпеченні суспільного життя у другій половині XX століття обумовило виникнення низки теорій регіонального розвитку, які мають значення і для розуміння чинників людського розвитку. 3 позицій формування умов людського розвитку територій, найбільш цікавими і такими, що пояснюють сучасні його тенденції є декілька напрямів регіональної економічної науки.

Однією із них є теорія саморозвитку регіону, яка базується на використанні внутрішніх ресурсів території. Посилення конкуренції регіонів та зростання зацікавленості регіонів у своєму розвитку обумовили потребу вдосконалення територіального управління за рахунок підвищення самодостатності регіонів на основі більш ефективного використання наявних ресурсів. Саморозвиток регіону, як здатність економіки регіону в конкретних умовах забезпечувати позитивну динаміку свого розвитку, здійснюється за рахунок природних, економічних, фінансових і людських ресурсів. При цьому важливу роль відіграють соціальні та соціокультурні ресурси демографічні показники, якість життя населення, ступінь розвитку населених пунктів, соціальна диференціація суспільства, рівень освіти, рівень поінформованості й виховання суспільства; стан системи охорони здоров'я населення регіону та інші [17].

У 1970-1990 роки в економічній науці почав розвиватися такий напрям як урбаністична економічна теорія [18-20] яка особливу роль в економічному розвитку країни i регіонів відводить містам, передусім великим. Урбаністична теорія започаткувала численні вектори досліджень, серед яких слід виокремити концепції центр-периферійного територіального розвитку, посилення агломераційних процесів і формування міських агломерацій.

Теорії центр-периферійного територіального розвитку та «полюсів зростання» досліджують чинники неоднорідності просторового розвитку та виокремлюють райониядра, зростаючі райони, периферійні та напівпериферійні райони, промислові і сільськогосподарські, кризові та депресивні райони, відводиться особлива роль містам як полюсам розвитку. Так, Дж. Фрідман [9] обгрунтував у розвитку територій роль центрів зростання, виникнення яких пов'язував з появою потужного ядра (агломерації) серед територіальних утворень, що формує полюс росту та впливає на велику периферію. Внаслідок цього невідворотно виникає просторова поляризація, яка породжує диспропорції між розвитком центру i периферії, наявність яких обумовлює нерівномірність умов для людського розвитку. Ф. Перру [10], відзначав, що полюси економічного зростання формуються на тих територіях, де розміщуються галузі i підприємства, які розвиваються більш динамічно і виробляють нові товари і послуги. Наявність підприємств, що динамічно розвиваються, забезпечують вищий рівень зайнятості, вищі доходи населення та створює кращі умови розвитку людського потенціалу завдяки підвищенню конкурентоспроможності регіону, зростанню економічного потенціалу.

В 90-і роки XX століття активно розвивається теорія міських агломерацій, які формуються внаслідок концентрації промисловості та високотехнологічних фірм. Дослідники відзначають позитивні ефекти агломерації, які мають значення i для розвитку людського потенціалу (формування ємного ринку товарів і послуг; розвиток виробничої і соціальної інфраструктури; масштабніше залучення кваліфікованої робочої сили; більш швидка передача знань і генерування соціально-економічних інновацій). Разом 3 тим, агломерації мають і негативні наслідки для соціального і людського розвитку, які пов'язані зі збільшенням віддаленості до місця роботи і об'єктів соціальної інфраструктури, виникненням деградуючих районів і зростанням злочинності [11]. 
Концепція сталого розвитку була сформована в 80-90-х роки XX століття багатьма дослідниками [12; 20-21]. Реалізація концепції сталого розвитку безпосередньо спрямована на людський розвиток і потребує цілеспрямованої соціально-економічної політики, яка знайшла вираження в Цілях Сталого Розвитку. В Україні є відповідне закріплення цих цілей на законодавчому рівні [22], що визначає спрямованість більшості стратегій регіонів України на забезпечення сталого розвитку своїх територій.

Систематизуємо взаємозв'язок сучасних теорій просторового розвитку з умовами та чинниками розвитку людського потенціалу територій (табл. 2).

Таблиця 2

\section{Взаємозв'язок сучасних теорій просторового розвитку з розвитком людського} потенціалу територій

\begin{tabular}{|c|c|c|}
\hline Teopiï & Автори & Значення для людського потенціалу \\
\hline $\begin{array}{l}\text { Tеорія саморозвитку регіону: розвиток } \\
\text { базується на використанні внутрішніх } \\
\text { ресурсів території }\end{array}$ & $\begin{array}{l}\text { М. Сторпер, } \\
\text { М. Кітінг, } \\
\text { А. Родрігес-Поза, } \\
\text { Р. Езкура }\end{array}$ & $\begin{array}{l}\text { Людський потенціал є ресурсом саморозвитку, що } \\
\text { обумовлює потребу збільшення чисельності } \\
\text { населення, підвищення якісних характеристик }\end{array}$ \\
\hline $\begin{array}{l}\text { Теорія центр-периферійного } \\
\text { територіального розвитку: просторова } \\
\text { поляризація і диспропорції між } \\
\text { розвитком центру і периферії } \\
\text { внаслідок концентрації ресурсів у } \\
\text { містах }\end{array}$ & $\begin{array}{l}\text { Дж. Фрідман, } \\
\text { М. Хейнденріх, } \\
\text { Д. Сепік, } \\
\text { П. Хаггет }\end{array}$ & $\begin{array}{l}\text { Обгрунтовує нерівномірність умов для людського } \\
\text { розвитку, оскільки центр, під яким розуміються } \\
\text { потужні осередки виробництва і розселення, } \\
\text { притягує ресурси, то в ньому формуються кращі } \\
\text { умови для розвитку людського потенціалу }\end{array}$ \\
\hline $\begin{array}{l}\text { Tеорія «полюсів зростання»: якими } \\
\text { являються міста, що володіють } \\
\text { комплексом пропульсивних галузей }\end{array}$ & $\begin{array}{l}\text { Ф. Перру } \\
\text { Ж. Будвіль, } \\
\text { Х. Ласуен }\end{array}$ & $\begin{array}{l}\text { Концентрація в містах підприємств, що швидко } \\
\text { розвиваються, забезпечує вищий рівень } \\
\text { зайнятості, вищі доходи населення та створює } \\
\text { кращі умови для розвитку людського потенціалу }\end{array}$ \\
\hline $\begin{array}{l}\text { Tеорія міських агломерацій: } \\
\text { компактного розташування міських } \\
\text { поселень, об'єднаних виробничими, } \\
\text { трудовими, побутовими, культурними } \\
\text { зв'язками. }\end{array}$ & $\begin{array}{l}\text { A. Venables } \\
\text { D. Lyons }\end{array}$ & $\begin{array}{l}\text { Виявляє позитивні ефекти агломерації для } \\
\text { розвитку людського потенціалу (формування } \\
\text { ємного ринку товарів і послуг, розвиток } \\
\text { соціальної інфраструктури, попит на } \\
\text { кваліфіковану робочу силу, забезпечення якісних } \\
\text { послуг) }\end{array}$ \\
\hline $\begin{array}{l}\text { Концепції сталого розвитку - } \\
\text { забезпечення збалансованого } \\
\text { економічного, екологічного й } \\
\text { соціального розвитку країн і регіонів } \\
\text { та формування повноцінного } \\
\text { життєвого середовища для сучасного і } \\
\text { наступних поколінь }\end{array}$ & $\begin{array}{l}\text { Г. Брундланд } \\
\text { Д. Герман }\end{array}$ & $\begin{array}{l}\text { Обгрунтовує необхіднісь вирішення соціальних } \\
\text { проблем бідності та безпечного життєвого } \\
\text { середовища для існування і розвитку людства } \\
\text { шляхом формування й реалізації цілеспрямованої } \\
\text { державної та регіональної політики для } \\
\text { досягнення Цілей сталого розвитку }\end{array}$ \\
\hline
\end{tabular}

Джерело: розроблено автором на основі [6-12; 17-20]

Слід відзначити, що окрім економічних, просторових, соціальних чинників, розвиток людського потенціалу території значною мірою залежить від інституційних чинників, передусім діяльності регіональних та місцевих органів влади. Саме діяльність територіальних органів влади вирішує проблеми людського розвитку, шляхом законодавчої, адміністративної та організаційної роботи створює умови для розвитку людини.

Проведений аналіз науково-теоретичних поглядів на соціально-економічний, технологічний і просторовий розвиток дав змогу розробити теоретико-методологічні засади соціально-економічних детермінант розвитку людського потенціалу території (регіону, міста), які системно викладені на рис. 1.

Ми виходимо 3 того, що основними детермінантами, тобто обмежуючими чинниками розвитку людського потенціалу регіону є його економічний, інноваційний та просторовий розвиток, який залежить не лише від наявних природних ресурсів, але і від діяльності місцевих органів влади, ефективності їх регіональної політики. 


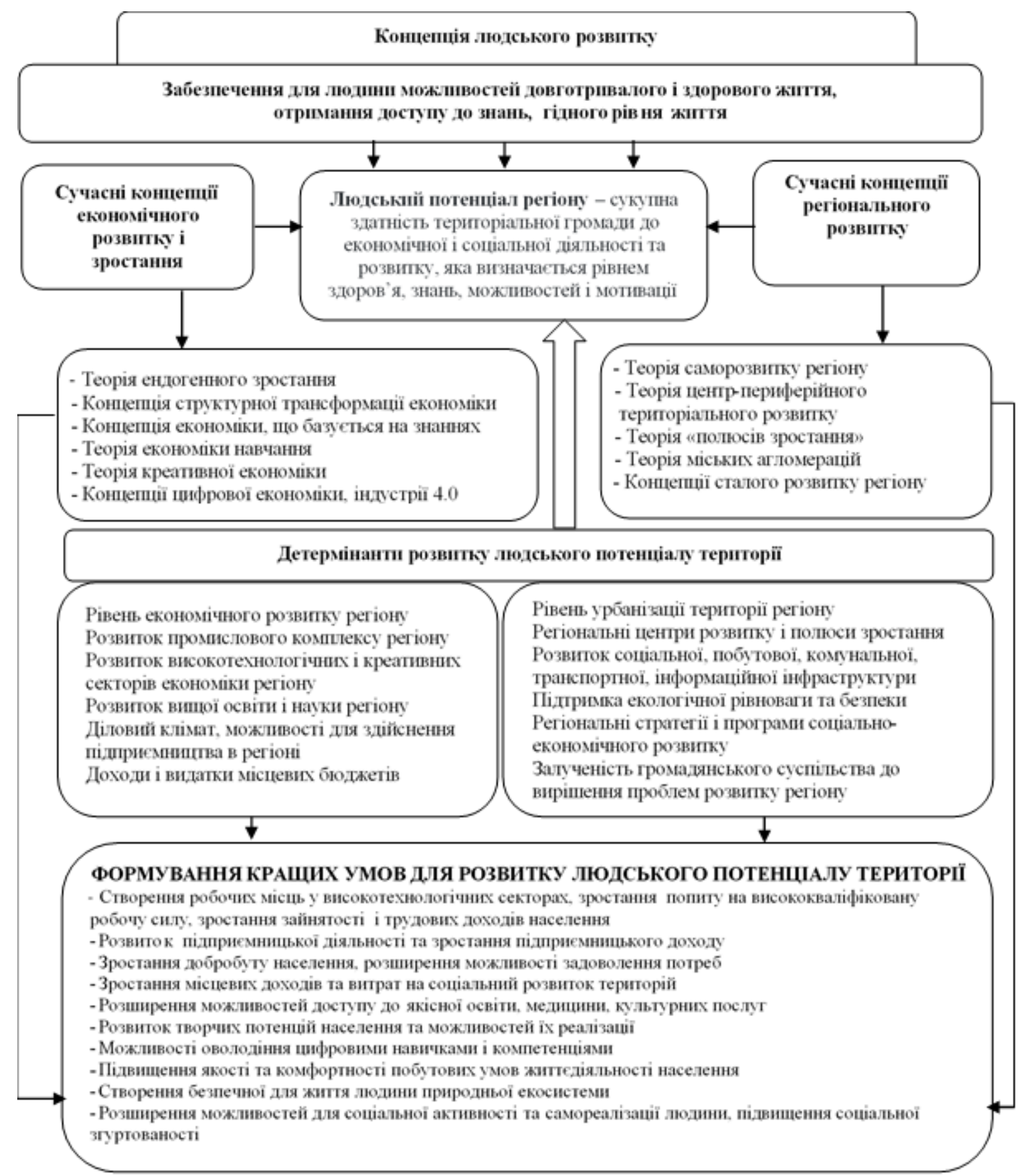

\section{Рисунок 1 - Теоретико-методологічне обгрунтування соціально-економічних детермінант розвитку людського потенціалу території}

Джерело: розроблено автором

Аналіз низки сучасних наукових концепцій економічного та регіонального розвитку дозволив систематизувати чинники, які визначають умови людського розвитку, та запропонувати низку показників їх оцінювання і вимірювання, що можна згрупувати у чотири блоки: економічний, просторовий розвиток, рівень добробуту, розвитку знаннєвої та креативної економіки. Ці показники не характеризують параметри людського потенціалу, а свідчать лише про наявність умов для його формування. Для оцінки людського потенціалу територій (регіонів, міст) доцільно використати низку інших показників (чисельність населення і його динаміка; очікувана тривалість життя; рівень здоров'я та захворюваності населення; рівень освіти, отриманих знань і 
кваліфікації; володіння цифровими навичками; здатність до творчої діяльності, яка проявляється у різноманітних формах; рівень заробітної плати та середньодушових доходів населення; підприємницька активність населення; соціальна і громадянська активність).

Для визначення ефективності політики території (регіону) в забезпечені умов розвитку людського потенціалу здійснимо порівняльну оцінку детермінант людського розвитку Вінницької, Житомирської, Хмельницької і Полтавської областей, як типових регіонів центральної частини України, що $є$ схожими за соціально-економічними та просторовими параметрами. Для оцінки відібрано 4 блоки статистично доступних показників, які характеризують соціально-економічні чинники формування і розвитку людського потенціалу.

1. Група показників економічного блоку: характеризують рівень та можливості економічного, інноваційного, підприємницького розвитку регіону, визначають потребу у висококваліфікованому і креативному людському потенціалі: ВРП (у факт. цінах) на одну особу населення, грн, частка переробної промисловості у ВДВ, \%, частка інтелектуальних і креативних ВЕД у ВДВ, \%, кількість середніх і малих підприємств у розрахунку на 10 тис. осіб наявного населення, одиниць, обсяг видатків місцевих бюджетів (з урахуванням міжбюджетних трансфертів) на одну особу, грн.

2. Група показників просторового блоку, які характеризують рівень урбанізації та розвиток соціальної інфраструктури: питома вага міського населення у загальній чисельності,\%, щільність автомобільних доріг загального користування 3 твердим покриттям, км. на 1 тис. кв. кілометрів, планова ємність амбулаторно-поліклінічних закладів на 10 тис. населення, кількість закладів загальної середньої освіти на 100 тис. населення, кількість закладів професійної (професійно-технічної) освіти на 100 тис. населення.

3. Група показників, щу характеризує добробут населення: наявний дохід населення у розрахунку на одну особу, грн. на рік, середньомісячна заробітна плата штатних працівників, грн., рівень зайнятості населення у віці 15-70 років, відсотків до економічно активного населення відповідного віку, \%, частка населення із середньодушовими еквівалентними загальними доходами на місяць нижче фактичного прожиткового мінімуму (ПМ),\%, загальна площа житлового фонду у розрахунку на 1 особу, кв. м.

4. Група показників, щзо характеризує розвиток знаннєвої та креативної економіки: кількість студентів університетів, інститутів на 10 тис. населення, частка випускників шкіл звітного року з атестатом про повну загальну середню освіту, \%, прийнятих на початковий цикл навчання до BHЗ III-IV p.a., кількість працівників, задіяних у виконанні НДР (на 100 тис. населення), частка домогосподарств, які мають доступ до Інтернету вдома, \%, частка зайнятих у сфері мистецтва, спорту, розваг і відпочинку в загальному обсязі зайнятих регіону, \%.

Усі відібрані показники, крім частки населення із середньодушовими еквівалентними загальними доходами на місяць нижче фактичного прожиткового мінімуму, є стимуляторами, тому чим вищий їх рівень, тим кращі умови для розвитку людського потенціалу регіону. Порівняльна оцінка детермінант розвитку людського потенціалу чотирьох регіонів здійснена за авторською методикою розрахунку часткових та узагальнених індексів за кожною складовою, сумарних індексів за блоками та узагальнених індексів за всіма показниками за всі роки дослідження - тобто за 2016-2018 pp. 2019 рік не залучено до аналізу, оскільки не за всіма показниками є дані.

Розрахунки зроблено за таким алгоритмом: 


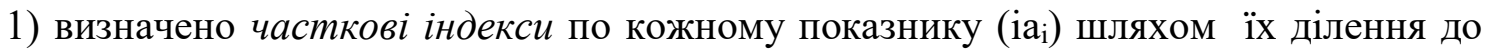
середнього значення по Україні, які взято в якості бази нормування;

2) визначено підсумкові індекси за кожним показником (іпі) як сума часткових індексів за всі роки дослідження. Виходили 3 того, що показники розвитку регіонів міняються із року в рік, тому найбільш достовірно характеризувати динаміку може сума індексів за кожним показником;

3) за кожним блоком показників визначено сумарні індекси регіонів ( $\mathrm{ic}_{\mathrm{j}}$ ), як підсумок усіх індексів усіх показників кожного блоку;

4) загальний Індекс сочіально-економічних детермінант розвитку людського потенціалу регіону (Іс-едЛП) визначається як сума усіх індексів за всіма блоками показників кожного регіону.

Результати розрахунку сумарних індексів регіонів за кожним блоком наведено на рис. 2.

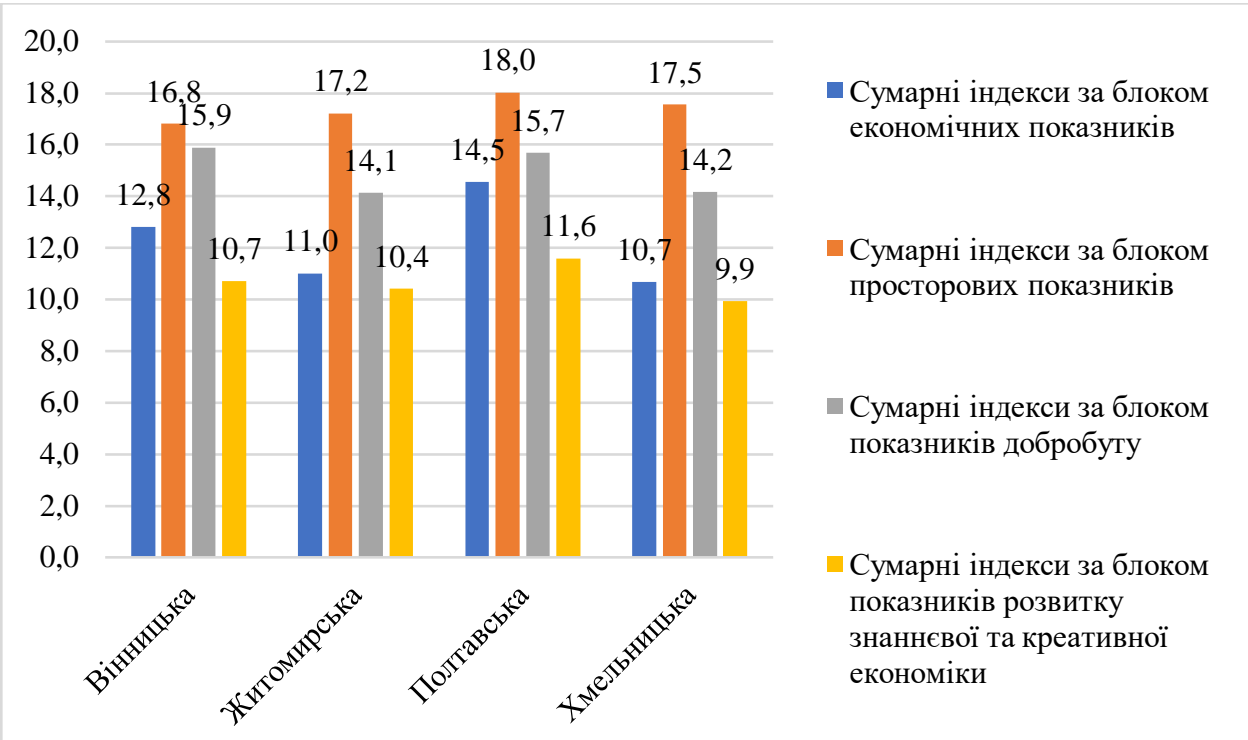

\section{Рисунок 2 - Сумарні індекси регіонів за кожним блоком за 2016-2018 роки}

За сумарним індексом економічного блоку лідирує Полтавська область завдяки більш високому рівню ВДВ на душу населення, Вінницька область посіла друге місце завдяки вищій частці переробної промисловості та інтелектуальних і креативних галузей.

Згідно сумарного індексу просторового блоку показників найкращі позиції також займає Полтавська область завдяки більш високому рівню урбанізації, ємності амбулаторно-поліклінічних закладів та кількості закладів ПТО, інші регіони характеризуються гіршими параметрами інфраструктурного забезпечення людського розвитку.

Аналіз показників за блоком добробуту свідчить про їх вищу сумарну якість у Вінницькій області, не зважаючи на те, що по трьох показниках кращі результати мала Полтавська область. Показники середньодушових доходів цього регіону, заробітної плати і зайнятості є нижчими їх середнього рівня по Україні, однак вищими ніж у Житомирській і Хмельницькій областях. В той же час вона має значно нижчу частку населення 3 доходами нижче фактичного прожиткового мінімуму та лідером забезпечення житловою площею серед досліджуваних областей.

Показники блоку розвитку знаннєвої та креативної економіки свідчать про значні відхилення від середніх значень по Україні. Беззаперечним лідером залишається Полтавська область завдяки більш високій кількості студентів ВНЗ, працівників НДР та 
частки домогосподарств із доступом в Інтернет. Вінницька область займає друге місце у зв'язку зі значно меншою кількістю студентів BНЗ III-IV рівнів акредитації на 10 тис. населення (на 21\%) з одночасно значно більшою часткою випускників шкіл, які поступають на навчання у ВНЗ. Це свідчить про те, що частина 3 них виїздить на навчання в інші регіони.

Значення розрахованого загального Індексу соиіально-економічних детермінант розвитку людського потенціалу регіонів свідчать, що найкращий результат має Полтавська область, яка за трьома блоками показників, окрім добробуту, займала перші місця (табл. 3). Вінницька область за посіла друге місце, вона поступається Полтавській області за цим показником на 3,634 бали, або на 6\% від значення найвищого індексу. Житомирська та Хмельницька області мають значно нижчі результати.

Таблиця 3

Сумарний індекс соціально-економічних детермінант розвитку людського потенціалу регіонів та ранги досліджуваних областей

\begin{tabular}{|l|c|c|}
\hline $\begin{array}{c}\text { Досліджувані } \\
\text { області }\end{array}$ & $\begin{array}{c}\text { Індекс соц.-екон. детермінант людського потенціалу } \\
(\text { Іс-едлп) }\end{array}$ & $\begin{array}{c}\text { Ранги } \\
\text { областей }\end{array}$ \\
\hline Вінницька & 56,25 & 2 \\
\hline Житомирська & 52,77 & 3 \\
\hline Полтавська & 59,84 & 1 \\
\hline Хмельницька & 52,29 & 4 \\
\hline
\end{tabular}

Джерело: розраховано автором за власною методикою

Проведене дослідження дозволяє обгрунтувати вплив сформованих соціальноекономічних детермінант на розвиток людського потенціалу територій (регіонів), визначити прогалини у економічному, просторовому, знаннєвому i креативному розвитку, а також рівні добробуту. Сфери відставання мають бути предметом особливої уваги і пріоритетів регіональних органів влади при визначення стратегій і програм регіонального розвитку.

Висновки. 3 огляду на зростаючу значущість людського чинника в забезпеченні динаміки економічного розвитку територій на сучасному етапі необхідний перегляд теоретико-методологічних підходів до систематизації розуміння соціально-економічних детермінант розвитку людського потенціалу територій. Проведене дослідження дозволило виявити соціально-економічні детермінанти розвитку людського потенціалу, які визначають потребу, умови і параметри його формування з позицій сучасних теорій економічного розвитку та концепцій регіонального розвитку. Конкретизовано перелік соціально-економічних детермінант людського розвитку регіону за блоками економічного, просторового розвитку, рівня добробуту, розвитку знаннєвої і креативної економіки, визначено їх вплив на умови і параметри розвитку людського потенціалу регіону. На основі використання запропонованих теоретико-методологічних підходів здійснено компаративний аналіз і оцінку соціально-економічних детермінант розвитку людського потенціалу типових регіонів центральної України (Вінницького, Житомирського, Полтавського і Хмельницького). Розраховано загальний індекс соціально-економічних детермінант розвитку людського потенціалу регіону, який виявив сфери відставання, що мають бути предметом особливої уваги і пріоритетів регіональних органів влади при визначення стратегій і програм регіонального розвитку. 


\section{СПИСОК ВИКОРИСТАНИХ ДЖЕРЕЛ}

1. Romer P.M. Increasing Returns and Long-Run Growth. Journal of Political Economy, 94, October, 1986. pp.1002-1037. DOI: http://dx.doi.org/10.1086/261420

2. Lucas R.E. On the Mechanics of Economic Development. Journal of Monetary Economics, 22, July, 1988. pp. 3-42. DOI: http://dx.doi.org/10.1016/0304-3932(88)90168-7

3. Hausmann R., Klinger B. (2007). The structure of the product space and the evolution of comparative advantage. CID Working Paper, No. 146

4. Knowledge-based Economy. OECD. GD. Paris, 1996. 49 p.

5. Lundvall B.-Å., Borras S. The globalising learning economy: Implications for innovation policy, DG XII, European Commission. Bruxelles, 1998.

6. Storper M. Agglomeration, Trade, And Spatial Development: Bringing Dynamics Back In. Journal of Regional Science, Wiley Blackwell, 2010. Vol. 50 (1). P. 313-342.

7. Китинг М. Новый регионализм в Западной Европе / пер. с англ. А. Смирнова. М.: Логос, 2003. № 6 (40). С. 67-116.

8. Rodríguez-Pose A. Is fiscal decentralization harmful for economic growth? Evidence from the OECD countries. Journal of Economic Geography, Oxford University Press. 2011. Vol. 11 (4), July. P. 619-643.

9. Friedman J. Urbaniezention Planing and Naitional Development. Beverly Hills, London, 1973.

10. Perroux F. Note on the Concept of Growth Poles. Regional Economics: Theory and Practice ; [edited by David McKee, Robert Dean, William Leahy]. NY: The Free Press, 1970. P. 93-103.

11. Шмидт А. В., Антонюк В. С., Франчини А. Городские агломерации в региональном развитии: теоретические, методические и прикладные аспекты. Экономика региона. 2016. Т. 12, вып. 3. С. 776-789.

12. Beyond Growth. The Economics of Sustainable Development. Herman E. Daly. Beacon Press, 1996. $253 \mathrm{p}$.

13. Крапивний І. В., Прокопенко О. В., Школа В. Ю. Концептуальні моделі економіки знань. Механізм регулювання економіки, 2015, № 1, с. 55-67.

14. Лошковська, Х. С. Тенденції розвитку креативності в контексті міжнародного бізнесу. Ефективна економіка, №3, $2014 . \quad$ URL: www.economy.nayka.com.ua/?op=1\&z=2860.

15. Концепція розвитку цифрової економіки та суспільства України на 2018-2020 роки. Схвалено розпорядженням Кабінету Міністрів України від 17 січня 2018 р. № 67.

16. Шваб К. Четверта промислова революція. Формуючи четверту промислову революцію. Переклад з англ. Харків, 2019, 416 с.

17. Іванова О. Ю. Фактори саморозвитку регіонів в умовах трансформаційних перетворень. Науковий вісник Херсонського державного університету. Серія Економічні науки. Випуск 13. Частина 3. 2015, с. 95-98

18. Jacobs J. The Economy of Cities. New York: Randon House, 1970. 288 p.

19. Evans A. W. Urban Economics (an introduction). Oxford: Publishers, 1992. 203 p.

20. Коритько Т.Ю. Формування організаційно-економічного механізму сталого розвитку регіону. Економіка і регіон. 2012. № 6(37). С. 25-29.

21. Бурик 3.М. Формування концепції сталого розвитку регіону. Теорія та практика державного управління і місцевого самоврядування. 2014, № 1 .

22. Концепція сталого розвитку населених пунктів. Схвалено Постановою Верховної Ради України від 24 грудня 1999 року N 1359-XIV. https://zakon.rada.gov.ua/laws/show/1359-14 


\section{REFERENCES}

1. Romer, P.M., (1986). Increasing Returns and Long-Run Growth. Journal of Political Economy, 94, pp.1002-1037. DOI: http://dx.doi.org/10.1086/261420

2. Lucas, R.E., (1988). On the Mechanics of Economic Development. Journal of Monetary Economics, 22, pp. 3-42. DOI: http://dx.doi.org/10.1016/0304-3932(88)90168-7

3. Hausmann R., Klinger B. (2007). The structure of the product space and the evolution of comparative advantage. CID Working Paper, No. 146

4. Knowledge-based Economy. OECD. GD. Paris, 1996. 49 p.

5. Lundvall, B.-A., Borras S. The globalising learning economy: Implications for innovation policy, DG XII, European Commission. Bruxelles, 1998.

6. Storper M. Agglomeration, Trade, And Spatial Development: Bringing Dynamics Back In. Journal of Regional Science, Wiley Blackwell, 2010. Vol. 50 (1). P. 313-342.

7. Kytyng M. (2003). Novyj regyonalyzm v Zapadnoj Evrope / per. s angl. A. Smyrnova. M.: Logos, 6 (40). pp. 67-116.

8. Rodríguez-Pose, A. (2011). Is fiscal decentralization harmful for economic growth? Evidence from the OECD countries. Journal of Economic Geography, Oxford University Press, 11 (4), pp. 619-643.

9. Friedman, J. (1973). Urbaniezention Planing and Naitional Development. Beverly Hills, London.

10. Perroux, F. (1970). Note on the Concept of Growth Poles. Regional Economics: Theory and Practice. NY: The Free Press. pp. 93-103.

11. Shmydt, A. V., Antonyuk, V. S., Franchyny, A. (2016). Gorodskye aglomeracyy v regyonalnom razvytyy: teoretycheskye, metodycheskye y prykladnie aspekti. Ekonomyka regyona. 2016. 12, 3. pp. 776-789.

12. Herman E. Daly (1996). Beyond Growth. The Economics of Sustainable Development. Beacon Press, 253 p.

13. Krapyvnyj, I. V., Prokopenko, O. V., Shkola, V. Yu. (2015). Konceptualni modeli ekonomiky znan. Mexanizm regulyuvannya ekonomiky, 1, pp. 55-67.

14. Loshkovska, X. S. (2014). Tendenciyi rozvytku kreatyvnosti v konteksti mizhnarodnogo biznesu. URL: www.economy.nayka.com.ua/?op=1\&z=2860 (Assessed on 10.11.2020).

15. Koncepciya rozvytku cyfrovoyi ekonomiky ta suspilstva Ukrayiny na 2018-2020 roky. Sxvaleno rozporyadzhennyam Kabinetu Ministriv Ukrayiny vid 17 sichnya 2018 r.

16. Shvab K. (2019). Chetverta promyslova revolyuciya. Formuyuchy chetvertu promyslovu revolyuciyu. Pereklad z angl. Xarkiv, $416 \mathrm{p}$.

17. Ivanova O. Yu. (2015). Faktory samorozvytku regioniv v umovax transformacijnyx peretvoren. Naukovyj visnyk Xersonskogo derzhavnogo universytetu. Seriya Ekonomichni nauky. Vypusk 13. Chastyna 3. pp. 95-98

18. Jacobs, J. (1970). The Economy of Cities. New York: Randon House, 288 p.

19. Evans, A. (1992). Urban Economics (an introduction). Oxford: Publishers, 203 p.

20. Korytko, T.Yu. (2012). Formuvannya organizacijno-ekonomichnogo mexanizmu stalogo rozvytku regionu. 6(37). pp. 25-29.

21. Buryk, Z.M. (2014). Formuvannya koncepciyi stalogo rozvytku regionu. Teoriya ta praktyka derzhavnogo upravlinnya i miscevogo samovryaduvannya. 1.

22. Koncepciya stalogo rozvytku naselenyx punktiv. Sxvaleno Postanovoyu Verxovnoyi Rady Ukrayiny vid 24 grudnya 1999 roku N 1359-XIV. 